Journal of Educational Science and Technology

Volume 4 Number 2 August 2018 page 103-110

p-ISSN:2460-1497 and e-ISSN: 2477-3840

DOI: http://dx.doi.org/10.26858/est.v4i2.6025

\title{
Instrument of Lecturer Performance and Student Activity In the Lecture at Primary School Teacher Education Program
}

\author{
Antonius Edy Setyawan ${ }^{1}$, Nelly Wedyawati ${ }^{2}$, Warkintin ${ }^{3}$ \\ ${ }^{1}$ Pendidikan Guru Sekolah Dasar, STKIP Persada Khatulistiwa Sintang, Indonesia \\ Email: edysetyawan.200286@ gmail.com, \\ ${ }^{2}$ Pendidikan Guru Sekolah Dasar, STKIP Persada Khatulistiwa Sintang, Indonesia \\ Email: nellywedywati@gmail.com, \\ ${ }^{3}$ Pendidikan Guru Sekolah Dasar, STKIP Persada Khatulistiwa Sintang, Indonesia \\ Email: warkintin@yahoo.co
}

(Received: July-2018; Reviewed: July-2018; Accepted: August-2018; Published: August-2018)

(O2018 -EST Graduate Program Universitas Negeri Makassar. This is an article with open access under license CC BY-NC-4.0 (https://creativecommons.org/licenses/by-nc/4.0/).

\begin{abstract}
The purpose of the study was to develop lecturer performance instruments to measure the ability of lecturers to bring lectures and instruments for student activities while attending the lecture. This study is a research and development $(R \& D)$ design developed from the instrument by Rusilowati, which included: (1) needs analysis, (2) determination of indicators and grids, (3) development of questions, (4) expert review, limited trials, field trial (is a cycle activity between review and revision), (5) analysis of trial results and (6) product assembly. The results of the study (1) indicators for lecturer performance instruments were: work ability, initiative in work, work quality, accuracy of work, lecturers' behavior and appearance, communication and nationalism. (2) indicators for lecture activity instruments: readiness to attend lectures, attendance in lectures and timeliness of completing assignments. (3) the instrument tested on 50 students and lecturers in the Primary School Teacher Education program at STKIP Persada Khatulistiwa Sintang shows that both instruments were valid and reliable. It was concluded that the two instruments can be applied because they were valid and reliable to measure lecturers in bringing lectures and student lecture activities while attending lectures.
\end{abstract}

Keywords: instrument; performance; lecturer; activity; student; lecture

\section{INTRODUCTION}

Evaluation has the very important role for any events, whether it is an educational program, learning or training, since it determined how well they run. Normally, the purpose of the evaluation is to find out whether the program that has been conducted (such as the programs mentioned earlier), can be conveyed to the participants well, or in accordance with the target / goal, or not at all. All participants or facilitator in a program should do evaluation so that in the future, it could be better and the number of targets that haven not been achieved could be minimized. The development of non-test instruments also has some steps that must be followed which are determining instrument specifications; writing the instruments; determining instrument scale; determining the scoring system; examining the instrument; assembling the instruments; doing trials; analyzing test results; fixing instruments; carrying out measurements; and interpreting measurement results. (Rusilowati, 2013).

RI Law Number 20 of 2003: 2008 suggested some purposes of studying evaluation 
including (1) to investigate the productivity and effectiveness of teaching and learning activities. (2) to improve and perfect teacher activities, (3) to improve, perfect and develop teaching and learning programs (4)to identify difficulties faced by students during learning activities and to finding solutions, and (5)to place students in the right teaching and learning situation according to their abilities. (Arifin, 2009) stated that the benefit of doing evaluation for students is to arouse their interest and motivation to learn, form their positive attitude towards learning, increase their understanding, help them in choosing learning methods that are good and right and introduce the position of students in class.

(Jabbarifar, 2009) stated that assessment is a process that includes four basic components including: 1) measuring improvements over time period, 2) motivating students to study, 3) evaluating teaching methods, and 4) ranking the students' ability based on their overall group evaluation. Lecture as a learning process in universities need to be planned, implemented, and evaluated regularly. Aspects that need to be evaluated from lecturer include (1) design, (2) syllabus, (3) content, (4) materials and (5) methods, Matiru, Mwangi \& Schettle (in Rusilowati: 2008). Planning, implementing and evaluating lectures are usually dominated by lecturers. However, the assessment of lectures still focuses on assessing studens' learning outcomes. (Rusilowati, 2017) stated that evaluation is a very important part in the learning process, but it is often ignored by teaching staff. Lecturers need to be encouraged to carry out evaluations not only for their students, but also for themselves. Evaluation by students to assess the performance of lecturers also needs to be encouraged.

(Jihad \& Haris, 2012) the purpose of evaluation is to find out whether an education program, teaching or training has been understood by the participants or not. Certain numbers or values are usually used as the passing grade to determine the understanding level of the program. If students are considered to have mastered the material, then they will be categorized as pass. On the contrary, if they are considered not yet mastering, then they are declared not pass.

At STKIP Persada Khatulistiwa, the final course grade is presented in two forms, letter and score. The equivalence of those scores is as follows: $\mathrm{A}=4, \mathrm{~B}=3, \mathrm{C}=2, \mathrm{D}=1$, and $\mathrm{E}=0$. $\mathrm{T}$ score means there is an incomplete assessment component e.g. the final semester evaluation. Students who obtain that score must soon complete the assessment within two weeks. Score $\mathrm{T}$ cannot be changed into $\mathrm{K}$, except if students cannot take the final semester due to serious reasons e.g. getting sick, having an accident or a disaster.

The final grade is only considered valid if the subject is registered in Students' Course Selection Sheet. Values printed in the List of Participants and Final Value are signed by the Lecturer. Whether a student is actively registered in the semester is proved by those two documents. All scores that do not meet the requirements of item (1) above are declared null. Grade Point (GP) is a number that shows student achievement or progress in one semester. It is calculated at the end of each semester. The calculation formula is as follows (rounding down if less than 0.05 , rounding up if the same / more than 0.05). GPA is used to determine the maximum credits that students can take in the next semester.

The quality of the lecture process can be determined by two factors, i.e. lecturers and students. Factors that need to be evaluated from the subject are (1) lecture design, (2) lecture syllabus, (3) lecture content, (4) lecture materials and (5) lecture method, Matiru, Mwangi \& Schettle. (Rusilowati, 2017) Lecture design and syllabus are components to support the routine duties of lecturers in planning. Materials and methods are the supporting components in managing and administering assignments. The lecturers' performance and competence in teaching plays an important role in improving the quality of higher education because it can boost the learning outcomes which acts as the main measurement of the learning success (Wedyawati, Lisa, \& Magdovia, 2018). Observations and evaluations can come up with meaningfull advice to improve teaching and evaluation that are important to make students participate more actively in teaching (Divall: 2012)

The objectives of this study are: (a) developing a lecture evaluation instrument to measure the performance of Primary School Teacher Education lecturers in giving lectures at STKIP Persada Khatulistiwa Sintang. (b) developing lecture evaluation instruments to measure Primary School Teacher Education student activities when attending lectures at STKIP Persada Khatulistiwa Sintang. (c) testing 
the validity and reliability of the evaluation process for Primary School Teacher Education students at STKIP Persada Khatulistiwa Sintang

\section{METHOD}

Because the tools that will be developed are to evaluate learning processes and outcomes, we made it in the non-test form. The development step of an evaluation tool is preceded by analyising the needs followed by developing questions (in the form of questions / statements), test questions and assembling evaluation tools. Needs analysis is begun with an initial survey of the real conditions in the field. The development procedure is illustrated in Figure 1. The stages of the research are as follows:

1. The need analysis is an activity to collect Primary School Teacher Education student learning outcomes data for the next 3 years: 2015, 2016 and 2017. From the data, we got the fact that $20 \%$ of the students' GPA scores are still $<2.75$.

2. Determination of indicators and grids is conducted by collecting and researching information by employing purposive study as the main activity. It reviewed both relevant literatures and previous studies on the development of lecture evaluation instruments.

3. The next step was developing questions, planning and developing the preliminary form of the product with some activities i.e. planning and preparing the lecture evaluation, and determining the parties that will be involved in this research, determining work procedures and doing feasibility test. The output of this activity was the evaluation draft for a lecture that is ready to be tested.

4. Expert review, limited trials and field trials aimed to improve the quality of the product. They were performed by the expert team on the field. At this stage, we analyzed and revised products. If the quality of the product was still poor, we revised and then validated it again. After the validation results were good, the product was ready to be tested in the field.

5. Field testing/implementation phase contained limited and wider trials. Individual testing was carried out by experts on teaching evaluation; while the field test was conducted by Primary School Teacher Education lecturers. Field trials were conducted to Primary School Teacher Education students.

6. Analysis of the trial results was to identify the validity and reliability of the draft that has been tested.

7. Assembling products was conducted by packing the instrument draft into a lecture evaluation book. The book will be registered to get the ISBN. Products will also be written in journals and presented in scientific seminars.

8. The types of data that were be collected are qualitative and quantitative. Qualitative data were obtained from expert inputs while quantitative data was from students' responses (score coding) on non-test assessment tools. The data was analysed using triangulation mix-method design by doing simultan analysis on qualitative and quantitative and combined data. Furthermore, the results of the analysis were taken as the basis for understanding the research problems. The weakness of a data will be complemented by others. Quantitative tests were performed statistically to determine the validity and reliability level of the lecture evaluation instrument. Meanwhile qualitative descriptive analysis was carried out on nontest data. 


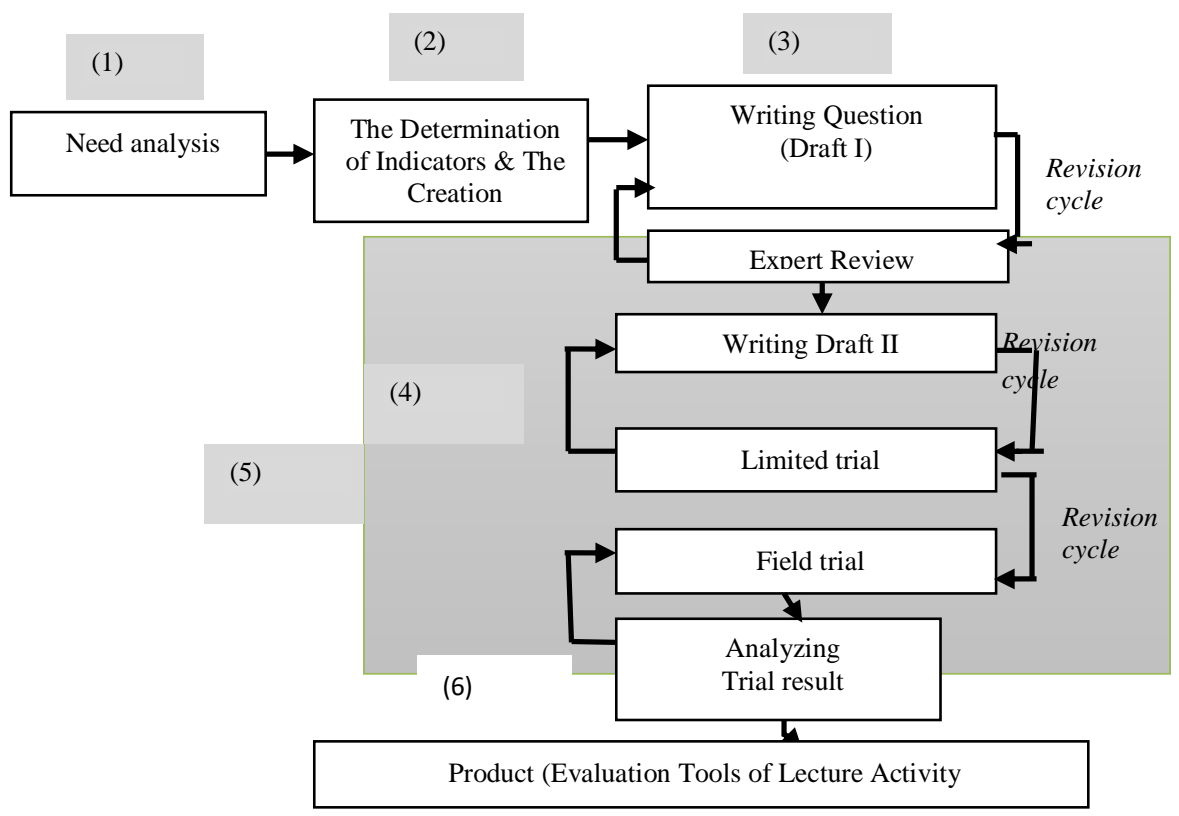

Figure 1. Instrument Development Steps

\section{RESULT AND DISCUSSION}

\section{Result}

The dimensions and indicators of the lecturers' performance and lecture activities are presented and described in table 2 and table 3. Grids that had been developed based on theory were then compiled to produce a draft evaluation of lecturers performance and student activity. The first draft was then validated by the learning evaluation expert. The results are summarized in table 4. Lecturer evaluation experts stated that the instrument drafts of both lecturer performance and lecture activity could be used with a slight revision. Some revisions that needed to be done were improving the language, removing ambiguity of statement, and ensuring the relevance between language and dimensions. After being repaired, we obtained the second instruments draft of lecturer and lecture activities. This draft was be tested on field and then analyzed to know its validity and reliability.

Tabel 2. Grids of Primary School Teacher Education lecturer performance instruments

\begin{tabular}{llc}
\hline \multicolumn{1}{c}{ Dimension } & \multicolumn{1}{c}{ Indicators } & $\begin{array}{c}\text { Question } \\
\text { No. }\end{array}$ \\
\hline Work ability & 1. Able to lead the Class & 1,2 \\
& 2. Able to manage teaching and learning interactions & 3 \\
\multirow{2}{*}{ Initiative at } & 3. Able to carry out assessment of learning outcomes & 4,5 \\
work & 1. Using learning media & 6,7 \\
& 2. Using various methods & 8 \\
The quality of & 3. Orderly administering assessment of learning outcomes & 9,10 \\
work & 1. Planning a learning program & 11 \\
& 2. Carrying out assessment of learning outcomes & 12 \\
& 3. Carrying out lectures & 13 \\
& 4. Applying the finding of research in learning & 14 \\
Work accuracy & 5. Using ICT in teaching to develop the students & 15 \\
& 1. Mastering material, structure, concepts, and science in the & 16 \\
& field of Primary School Teacher Education & \\
\hline
\end{tabular}




\begin{tabular}{llc}
\hline & 2. Mastering the competency achievements on the Primary & 17 \\
& School Teacher Education field & \\
3. Completing the teaching program right on schedule & 18,19 \\
Lecturer & 1. Behaving in accordance with legal, social and cultural & 20 \\
Behavior and & norms & 21,22 \\
Appearance & 2. Upholding the attitude of pluralism / tolerance & 23 \\
& 3. Showing him/herself as an honest, noble, and exemplary & \\
& person for students & 24 \\
& 4. Showing yourself as a person who is steady, stable, mature, & \\
& wise, and authoritative & 25 \\
& 5. Demonstrating work ethic, high responsibility, a sense of & \\
& pride in being a lecturer, and confidence & 26 \\
6. Upholding the code of ethics on the teaching profession & 27,28 \\
Communication & 1. Implementing guidance services & 29 \\
& 2. Carrying out new things in lectures & 30 \\
& 3. Providing feedback to students & 31,32 \\
& 4. Being open to accept any input for learning improvements. & 33 \\
1. Adapting to a place with socio-cultural diversity & 34 \\
& 2. Acting objectively and not discriminatory on gender, \\
religion, race, physical condition, family background, and & \\
\hline Nocial status & \\
\hline
\end{tabular}

The results of literature study and Focus Group Discussion (FGD) conducted with a number of peers generated some indicators of lecturer performance evaluation tools which are presented in table 2. Lecturer performance is a description of the activity when giving lectures. In this case, some routine tasks of a lecturer include planning, managing and administering.
Some dimensions related to lecturer performance are: work ability, initiative in work, quality of work, accuracy of work, behavior and appearance of lecturers, communication, and nationalism. Performance is the score obtained by the lecturer after answering the lecturer performance questionnaire instrument with a scale of $1-4$

Table 3. Grids and indicators of students' activities when joining a lecture

\begin{tabular}{clc}
\hline \multicolumn{1}{c}{ Dimension } & \multicolumn{1}{c}{ Indicators } & $\begin{array}{c}\text { Question } \\
\text { No. }\end{array}$ \\
\hline Readiness in Lectures & 1. Physical Readiness in lectures & 1,2 \\
& 2. Mental readiness in lectures & 3,4 \\
& 3. Emotional readiness in lectures & 5,6 \\
4. Intellectual Readiness in lectures & 7 \\
The Existence in & 5. Actively paying attention to lecturer & 8 \\
lectures & $\begin{array}{l}\text { explanations } \\
\text { 6. Actively responding to what the lecturer }\end{array}$ & 9 \\
& delivered & 10 \\
& 7. Actively asking the lecturer & 11 \\
& 8. Actively answering lecturer questions & 12 \\
9. Give input to the lecturer & 13 \\
Punctuality in & 10. Carrying out the tasks given by the lecturer & \\
& earnestly & 14 \\
\hline
\end{tabular}


From the literature review and focus group discussion (FG4 + D) with several peers, we obtained indicators of evaluation tools for lecture activities which are presented in table 3. Conceptually, the definition of activities is students' actions during the lecture process. The operational definition is the score obtained by students after answering the questionnaire about a lecture they attended, with a scale of 1-4. The instrument for evaluating the students' activities was developed in the form of an objective questionnaire. The answer score of the four answer options rangesdfrom the highest to the lowest score.

After obtaining the results of the evaluation tools development, the next stage was the review from learning evaluation experts. (Wedyawati \& Lisa, 2017) stated that tests for measuring attitudes typically use a Likert scale. The Likert test consists of positive and negative statements. Assessment sheets obtained from experts were prepared based on the needs and objectives of the study with aspects i.e. the linkages of indicators with the objectives of the study, the suitability of the questions with the indicators measured, and the suitability of the questions with the objectives and the accuracy of language use. The results of evaluation from learning expert are presented in table 4 below.

Table 4. Assessments result summary from experts of lecturer evaluation

\begin{tabular}{|c|c|c|c|}
\hline \multirow[t]{2}{*}{ Criteria } & \multirow[t]{2}{*}{ Indicator } & \multicolumn{2}{|c|}{ Assessment Scale (\%) } \\
\hline & & $\begin{array}{c}\text { Lecturer } \\
\text { Performance }\end{array}$ & Lecture activities \\
\hline \multirow[t]{6}{*}{$\begin{array}{l}\text { Assessment } \\
\text { aspects }\end{array}$} & $\begin{array}{l}\text { A. Linkages of Indicators with } \\
\text { Objectives }\end{array}$ & 100 & 100 \\
\hline & $\begin{array}{l}\text { B. Suitability of Questions with } \\
\text { Measured Indicators }\end{array}$ & 100 & 100 \\
\hline & $\begin{array}{l}\text { C. Suitability of Questions with } \\
\text { Objectives }\end{array}$ & 100 & 100 \\
\hline & $\begin{array}{l}\text { D. The quality and the accuracy } \\
\text { of language }\end{array}$ & 100 & 100 \\
\hline & Average & 100 & 100 \\
\hline & Conclusion & $\begin{array}{l}\text { Can be applied with } \\
\text { minor revision }\end{array}$ & $\begin{array}{l}\text { Can be applied with minor } \\
\text { revision }\end{array}$ \\
\hline
\end{tabular}

\section{Discussion}

Based on the results of review from experts, in general, we concluded that this evaluation tools can be used but need minor revisions. The next stage was field trials. Field trials were carried out to 50 fourth semester Primary School Teacher Education students for testing the lecture activity scale, and to 1 lecturer to test lecturer performance scale. The questionnaire was designed with a Likert scale and analyzed by calculating the percentage of the answers which were ranged from strongly agree, agree, disagree, and strongly disagree. The validity of the questionnaire results was analyzed.
Validity test is an assesment used to identify the ability of measurement in assessing something. Based on the analysis of lecturer performance instruments with $\mathrm{n}=50$ and $\mathrm{r}_{\text {table }}=$ 0.279 , we found that 3 items were invalid so they were revised. The calculation in validity analysis showed that all items were larger than $r$ table so we concluded that all items were valid. Valid means that the instrument can be used to measure what should be measured. Therefore, items were declared valid and could be used in the research.

The reliability was tested to determine the consistency of the instrument, whether the measuring device used was reliable and remained consistent if the measurement was repeated. In testing the reliability, we applied 
Alpha (Cronbach's) method. (Sugiyono, 2015) The alpha method was very suitable for scores in the form of scales (eg 1-4, 1-5). Decision making criteria used a limit of 0.6 . According to Sekaran, the reliability which was less than 0.6 was categorized as not good, while 0.7 was acceptable and above 0.8 was good. All valid items were tested to determine their reliability. This test shows that all items were valid.

Calculations showed that all items of lecturer performance instruments were reliable. Analysis of the lecture activity evaluation tool with $\mathrm{n}=50$ with $\mathrm{r}_{\text {table }} 0.279$ indicated that all 14 items were valid so that all of them could be apllied. Valid means that the instrument can be used to measure what should be measured. Therefore, it can be concluded that items that were declared valid can be applied for research.

Reliability testing with the Alpha method (Cronbach's) employed a decision making criterion of 0.6. According to Sekaran: reliability which was less than 0.6 categorised as poor, while 0.7 was acceptable and above 0.8 was good. The output analysis showed a cronbach value of 0.981 . Because it was greater than 0.8 , it means that all items for the instrument of lecture activity were reliable.

By using valid and reliable instruments in data collection, the results of the study were expected to be valid and reliable. Validity and reliability of an instrument were the absolute requirements to get valid and reliable results. Evaluation also provides benefits for parties involved in the program. (Bangg: 2016) concluded that an evaluation in teaching could provide a systematic and specific plan to diagnose and improve teaching competencies.

Students as class participants should be interviewed to know what they thought about the lecture process that they followed. From the interview, it was found that students were very interested in the lecture process. By evaluating the development of lecturer performance and lecture activities evaluation tools, students had learned to do scientific activities that were useful for their skills as observers. (Setyawan, 2018) To evaluate, observers had to be good in doing assessment. That is, students were given the opportunity to learn to do evaluation and practice being intelligent observers.

\section{CONCLUSIONS AND SUGGESTION}

Some conclusions in the study are as follows: (a) The lecture evaluation instrument for the performance of Primary School Teacher Education lecturers at STKIP Persada Khatulistiwa Sintang found indicators derived from: (1) the work ability component including: able to lead the class, able to manage teaching and learning interactions, and able to carry out assessment of learning outcomes; (2) initiative in work including: using learning media, using various methods, orderly in administering assessment for the learning outcomes; (3) work quality including: planning teaching programs, planning assessment for teaching outcomes, conducting lectures, applying research results in teaching, utilizing ICT in learning to develop themselves; (4) the accuracy of work including: mastering the material, structure, concepts in the Primary School Teacher Education field, mastering the competency achievements of the Primary School Teacher Education field, and completing the teaching program on schedule; (5) lecturer behavior and appearance including: behaving in accordance with legal norms, social and culture, upholding pluralism / tolerance attitude, presenting themselves as honest, noble and a role mode for students, showing themselves as a stable, mature, wise and authoritative person, demonstrating work ethic, high responsibility, proud and confident to be a lecturer; (6) communication including: carrying out guidance services, implementing new things in lectures, providing feedback for students, being open in receiving input for improvements in learning; and (7) nationalism including: being able to adapt in a place with socio-cultural diversity, acting objectively and not doing any discrimination on gender, religion, race, physical condition, background, family and social status. (b) Lecture evaluation instruments for Primary School Teacher Education student activities when attending lectures found indicators derived from: (1) readiness in lectures including: physical, mental, emotional and intellectual readiness; (2) the presence in the lecture including: paying attention to the lecturer explanation, actively responding to what the lecturer conveyed, actively asking questions, actively giving answers / responses / objections, giving input to the lecturer; and (3) the punctuality to complete the task including: seriously carrying out the tasks given by the lecturer and submitting tasks on time. Evaluation instrument for lectures and activities of Primary School Teacher Education students at STKIP Persada Khatulistiwa Sintang Valid with values which was greater than $r_{\text {tabel }}$ and 
Reliable with values above 0.8 . (c) To achieve a better result, there should be other development researches for other variables based on the real conditions of the university environment and another implemention on a large scale in other universities to see the real impact of the results

\section{ACKNOWLEDGEMENT}

The authors express their deepest gratitude to: Lord Jesus for His gifts and blessings so that they can carry out and complete this scientific work. Thanks to the Directorate of Research and Community Service, Directorate General of Research and Development Enhancement, Ministry of Research, Technology and Higher Education with Research Contract 115 / SP2H / LT / DRPM / 2018 and Kopertis XI and Institute for Research and Community Service (LPPM) STKIP Persada Khatulistiwa Sintang for facilitating this research.

\section{REFERENCES}

Arifin, Z. (2009). Evaluasi Pembelajaran. Bandung: Remaja Rosda Karya.

Diknas. (2008). Sistem Pendidikan Nasional . Jakarta: Visi Media.

Divall, M., Barr, J., and Gonyeau., M. (2012). Follow-up Assessment of a Faculty Peer Observation and Evaluation Program. American Journal of pharmaceutical education, 76(4): 61.

Jabbarifar, Taghi. (2009). The Importance of Classroom Assessment and Evaluation in Educational System. Proceedings of the 2nd International Conference of Teaching and Learning (ICTL 2009) INTI University College, Malaysia.1-9

Jihad, A., \& Haris, A. (2012). Evaluasi Pembelajaran . Yogyakarta: Multi Pressindo.
Kim H Bangg, Kim Jinsoo. 2016. Development and Validation of Evaluation Indicators for Teaching Competency in STEAM Education in Korea. Eurasia Journal of Mathematics, Science \& Technology Education, 12(7): 1909-1924.

Rusilowati, A. (2008). Pengembangan Indikator Evaluasi Proses Perkuliahan di Perguruan Tinggi. Lembar Ilmu Kependidikan , 152159.

Rusilowati, A. (2017). Pengembangan Instrumen Penilaian . Semarang: Unnes Press.

Rusilowati. (2013). Pengembangan Instrumen Nontes. Seminar Nasional Evaluasi Pendidikan (p. 7-22). Semarang: Universitas Negeri Semarang.

Setyawan, A., E., Wedyawati, N., \& Warkintin. (2018). Developing Of Lectures Process Evaluation Tool Of Elementary School Teacher Study Program. Prosedding International Conference Education Culture and Technology $1^{\text {St }}$ ICONECT, Muria Kudus University.

Sugiyono, A. (2015). Metode Penelitian Kuantitatif Kualitatif dan RND. Jakarta: Raja Grafindo Persada.

Wedyawati, N., \& Lisa, Y. (2017). Developing Integrated Natural Sciences Disaster Mitigation Model For Elementary School Sintang. Jurnal of Education Science and Technology (EST) Volume 3 Nomor 2, 164172.

Wedyawati, N., Lisa, Y., \& Magdovia, E. (2018). Efektivitas model Pembelajaran IPA Mitigasi Bencana terhadap Hasil Belajar Siswa Sekolah Dasar. Jurnal Pendidikan Dasar Indonesia , 3 (1), 9-13. 